\title{
Analysis of eight genes modulating interferon gamma and human genetic susceptibility to tuberculosis: a case-control association study
}

\author{
Marlo Möller*1, Almut Nebel2, Paul D van Helden'1, Stefan Schreiber² and Eileen G Hoal
}

\begin{abstract}
Background: Interferon gamma is a major macrophage-activating cytokine during infection with Mycobacterium tuberculosis, the causative pathogen of tuberculosis, and its role has been well established in animal models and in humans. This cytokine is produced by activated T helper 1 cells, which can best deal with intracellular pathogens such as M. tuberculosis. Based on the hypothesis that genes which regulate interferon gamma may influence tuberculosis susceptibility, we investigated polymorphisms in eight candidate genes.

Methods: Fifty-four polymorphisms in eight candidate genes were genotyped in over 800 tuberculosis cases and healthy controls in a population-based case-control association study in a South African population. Genotyping methods used included the SNPlex Genotyping System ${ }^{\mathrm{TM}}$, capillary electrophoresis of fluorescently labelled PCR products, TaqMan ${ }^{\circ}$ SNP genotyping assays or the amplification mutation refraction system. Single polymorphisms as well as haplotypes of the variants were tested for association with TB using statistical analyses.

Results: A haplotype in interleukin 12B was nominally associated with tuberculosis ( $p=0.02$ ), but after permutation testing, done to assess the significance for the entire analysis, this was not globally significant. In addition a novel allele was found for the interleukin 12B D5S2941 microsatellite.

Conclusions: This study highlights the importance of using larger sample sizes when attempting validation of previously reported genetic associations. Initial studies may be false positives or may propose a stronger genetic effect than subsequently found to be the case.
\end{abstract}

\section{Background}

Infection with the tuberculosis (TB) agent Mycobacterium tuberculosis ( $M$. tuberculosis) and its subsequent outcomes (active TB, latent infection or clearance of the bacterium by the pulmonary immune system) are complex traits due to interactions between numerous host genetic susceptibility factors and the environment. Heritability analyses have shown that an individual's immune response to TB infection will be regulated by the genetic background, with an estimated heritability ranging from $36 \%$ to $80 \%$ [1-6]. Although many of the host genetic factors involved in TB still remain unidentified, several sus-

* Correspondence: marlom@sun.ac.za

1 Molecular Biology and Human Genetics, MRC Centre for Molecular and Cellular Biology and the DST/NRF Centre of Excellence for Biomedical TB Research, Faculty of Health Sciences, PO Box 19063, Stellenbosch University, Tygerberg 7505, South Africa

Full list of author information is available at the end of the article ceptibility genes have been repeatedly associated with the disease in different populations $[7,8]$.

Interferon gamma (IFN- $\gamma$ ) is a member of the interferon family which plays a crucial role in the reaction of the immune system in resistance to pathogens such as $M$. tuberculosis. There has been a great deal of interest in this cytokine since its discovery, because the macrophage, an important target cell of IFN- $\gamma$, is a fundamental role player in the immune system. The T helper 1 (Th1) cell response, which is required to contain $M$. tuberculosis infection, is largely characterised by IFN- $\gamma$ production. However production of this cytokine alone is not sufficient to protect against disease [9]. Even so, convincing evidence for its importance in the control of mycobacterial infections has been found in both experimental and clinical studies. Mice with a disrupted IFN- $\gamma$ gene (IFNG) show increased susceptibility to TB [10] and replacement 
of the gene into the lung confers resistance [11]. In most TB patients the production of $M$. tuberculosis-induced IFN- $\gamma$ by peripheral blood mononuclear cells is reduced at the time of diagnosis [12]. During and after successful treatment, these levels increase significantly [13]. It is also known that the IFN- $\gamma$ concentrations in sputum and bronchoalveolar lavage fluid can be used as an estimate of disease activity via a direct correlation [14]. Although IFN- $\gamma$ is required for an initial protective Th1 cell response to $M$. tuberculosis, the increased production of this cytokine post-infection is indicative of the risk of developing active TB. A recent study showed that macaque monkeys with high IFN- $\gamma$ levels two months post infection with $M$. tuberculosis were more likely to develop active TB [15] and similar observations have been made in humans $[16,17]$, perhaps indicating a failed immune response. Some experimental data have suggested that IFN- $\gamma$ is a correlate of protective immunity against TB $[18,19]$, although other studies in humans, mice and cattle do not support this [20-22]. Humans with mutations in genes of the interleukin 12/interleukin 23/ IFN- $\gamma$ axis have an increased susceptibility to even nonpathogenic mycobacteria and are extremely susceptible to M. tuberculosis and Salmonella, but not to other bacteria (reviewed by [23]). These mutations are all associated with the rare human syndrome known as Mendelian susceptibility to mycobacterial disease (MSMD).

In addition to the experimental and clinical studies discussed above, genetic association studies have also suggested that IFN- $\gamma$ is important in protecting against mycobacterial infection. The functional +874ATT single nucleotide polymorphism (SNP), a common variant in the IFNG gene, has been associated with TB in the South African Coloured population (SAC) [24] and various others [25] and even appears to be clinically relevant in sputum conversion in patients [26]. However, since TB is a complex disease and several genes are involved in its pathogenesis, it is possible that genes regulating IFN- $\gamma$ levels could also contain variants contributing to susceptibility.

Given the clinical and experimental evidence showing a crucial role of the IFN- $\gamma$ pathway in host defence against $\mathrm{TB}$, we investigated eight candidate genes which could potentially modulate the function of this vital cytokine, namely interleukin 4 (IL4), interleukin 10 (IL1O), interleukin 12B (IL12B), interleukin 12 receptor beta 1 (IL12RB1), interleukin 12 receptor beta 2 (IL12RB2), interleukin 18 (IL18), wingless-type MMTV integration site family, member 5A (WNT5A) and frizzled homolog 5 (FZD5). Fifty-four polymorphisms in these genes were genotyped and evaluated using a case-control association analysis in the SAC population. We found a novel allele of the IL12B microsatellite D5S2941 and showed the signifi- cance of using larger sample sizes when attempting validation of previously reported genetic associations.

\section{Methods \\ Study population}

This study was carried out in the Cape Town metropolitan area of the Western Cape Province of South Africa, where TB is endemic and the estimated prevalence of the human immunodeficiency virus (HIV) among adults is approximately $2 \%$ [27]. The incidence of TB in this province was 1005 per 100000 population during 2007 [28]. All study participants were from the SAC population. This unique population is a group of mixed ancestry, which dates back several generations, and has San, Khoi, Malaysian, African black and European genetic contributions. In a previous study no evidence of significant population stratification was found for this population ( $\mathrm{p}=$ 0.26) [29]. Informed consent was obtained from all subjects included in this study. Blood samples were collected with the approval of the Ethics Committee of the Faculty of Health Sciences, Stellenbosch University (project number 95/072), and DNA purified by standard methods. Known HIV positive individuals were excluded from the study. Patients $(n=432$, age in years $=34 \pm 14.8$, males $=$ $53 \%$ ) were confirmed as having $\mathrm{TB}$ by bacteriological analyses. Controls $(n=482$, age in years $=27 \pm 12.3$, males $=23 \%$ ) were healthy individuals with no history of TB who live in the same high incidence community as the patients and were therefore most likely exposed to the bacterium.

\section{Genotyping}

Polymorphisms were selected from the literature (based on previous associations (Additional file 1) or functional effects) and dbSNP (Additional file 2). Genotyping of the 54 variants was done by the SNPlex Genotyping System ${ }^{\text {тм }}$ (Applied Biosystems), capillary electrophoresis of fluorescently labelled PCR products [30], TaqMan ${ }^{\circ}$ SNP genotyping assays (Applied Biosystems) [31,32] or the amplification mutation refraction system (ARMS-PCR) [33].

\section{Statistical analysis}

Since the allele frequencies of the polymorphisms analysed in this study were not known for the SAC population prior to the completion of genotyping and were necessary for power calculations before starting the experiment, we estimated from prior data that each SNP would at least have a minor allele frequency of $5 \%$ in our study group. Given this assumption we had 95\% confidence (alpha error $\mathrm{p}=0.05$ ) and $80 \%$ power (beta error $=0.2$ ) to detect an odds ratio of at least 2.15 with the number of samples available (432 cases and 482 controls). After genotyping, power calculations were done with the experimentally 
determined allele frequencies of the SNPs previously associated with tuberculosis to confirm that we had enough power to exclude the previously reported genetic effect sizes in the SAC population. All power calculations were done with Epi Info 2000 (Centers for disease control and prevention, USA). Hardy-Weinberg equilibrium was assessed for all SNPs.

Contingency tables of the distribution of genotypes between cases and controls were analysed by the chisquare test or the Fisher's exact test where appropriate. For the IL12B D5S2941 (rs10631390) microsatellite marker the number of ATT repeats was determined by direct counting and plotted as a distribution graph. Since this graph was bimodal, the alleles were divided into two subclasses, as previously described [34-36]. The shorter repeats, with $(\mathrm{ATT})_{7}$ and $(\mathrm{ATT})_{8}$, were designated as $\mathrm{S}$ alleles and the longer repeats, with (ATT) ${ }_{9}$ and $(\mathrm{ATT})_{10}$, were designated as $\mathrm{L}$ alleles. Prism version 4.02 was used to calculate p-values for single-point associations (Additional file 2).

Bonferroni corrections for multiple testing were done by considering the number of independent linkage disequilibrium (LD) blocks per gene [37]. We determined twenty-one independent tests and consequently a p-value of 0.002 was adopted as a threshold for significance. Haplotype frequencies were inferred using the COCAPHASE program that is part of the UNPHASED suite [38], http:// portal.litbio.org/Registered/Webapp/glue/). Haplotype blocks were selected with Haploview [39] by considering LD blocks. Global significance for haplotype analyses were tested with COCAPHASE and 10000 permutation replications were done.

\section{Results and discussion}

We genotyped 53 SNPs and 1 short tandem repeat (STR) in a large collection of SAC TB patients $(n=432)$ and controls $(n=482)$. All variants were in Hardy-Weinberg equilibrium in the control population. Four SNPs (rs2070874 in $I L 4$, rs2853639 in $I L 12 B$ and rs566926 and rs7622120 in $W N T 5 A$ ) were nominally associated with disease $(\mathrm{p}<0.05)$, but these were no longer considered to be statistically significant after adjusting our threshold of significance $(\mathrm{p}=0.002)$ to correct for multiple tests (Additional file 2). More importantly, however, our study did not replicate previously reported associations of $I L 4$, IL10, IL12B and IL12RB1 polymorphisms with TB (Additional files 1 and 2).

Polymorphisms in the IL4 promoter could influence the transcription levels of that gene. Specifically, a functional SNP (rs2243250, IL-4-C590T), located 589 bp upstream of the transcriptional site, has been associated with increased promoter strength, stronger binding of transcription factors and with different levels of IL-4 activity $[40,41]$, but was not associated with TB in our study. The
CC genotype of this polymorphism was previously associated with protection against pulmonary TB in south India and Russia [42,43], but not in The Gambia [44]. A possibility is that alternative splicing, and not increased expression of the $I L 4$ gene, is the actual regulatory mechanism in the production of IL-4, since the product of alternative splicing, namely IL- $4 \delta 2$, is a competitive antagonist of IL-4 [45]. Individuals with latent TB infection, but who remain healthy, have high levels of this variant mRNA [46]. During chemotherapy, IL-4 $\delta 2$, but not IL-4, levels increased in HIV positive and negative patients with TB [47]. In addition, there is a difference in the stability of the two IL4 mRNA products in TB patients, with IL- 4 being more stable than IL- $4 \delta 2$ [48]. Therefore the ratio of IL- 4 and IL- $4 \delta 2$ may play a role in disease progression, treatment or outcome, rather than the phenotype "diseased" per se [48]. An example of a gene involved in response to TB treatment is the vitamin $\mathrm{D}$ receptor gene $(V D R)$. The time taken for an individual to convert to sputum negativity while receiving TB chemotherapy could be independently predicted by the $V D R$ genotype, even though the $V D R$ polymorphisms were not associated with TB disease [49]. The apparent exclusion of a significant genetic effect of IL4 in TB susceptibility is therefore not an indication that the cytokine does not have a function in TB disease.

The three most frequently investigated polymorphic variants in $I L 10$ (rs1800872, rs1800871 and rs1800896) were not associated with TB in our study. These SNPs are linked and in most cases three haplotypes (CCG, ATA and CCA) are observed [50]. The haplotypes and individual SNPs have been shown to correlate with IL-10 production, transcriptional activity and nuclear-binding activity [50-53]. The rs 1800896 SNP has previously been associated with TB in Cambodia [54], Sicily [55] and Turkey [56], but not in China [57], The Gambia [58], Malawi [59], India [60], Spain [61] or Korea [62]. A smaller, second study done in Korea found that this polymorphism was associated with new and recurrent TB [63]. A recent meta-analysis found no evidence for association between TB and this SNP [25]. The rs1800872 SNP is in complete linkage disequilibrium (LD) with rs1800871 and these SNPs were associated with TB in Korea [62], but not in The Gambia, Malawi, China, Colombia, Turkey or Uganda [56-59,64-66]. Since the three-SNP haplotype of IL10 was previously associated with TB, we also tested this in the SAC population. In contrast to other studies $[56,65]$, there was no association evident in our analysis (Table 1). A four-SNP haplotype previously associated with TB in Korea [62], consisting of rs1800896, rs1800871, rs1800872 and rs3024496, was also not associated with disease in this study (Table 2). Stein et al. found that a three-SNP haplotype consisting of rs1518111, rs1554286 and rs1800872 was associated with protection 
Table 1: IL10 three SNP haplotype analysis.

\begin{tabular}{lllll}
\hline Block 1a & & Frequency Cases & Frequency Controls & p value \\
\hline 1 & C-C-A & 0.37 & 0.34 & 0.10 \\
\hline 2 & A-T-A & 0.31 & 0.34 & 0.08 \\
\hline 3 & C-C-G & 0.32 & 0.32 & 0.92 \\
\hline Global significanceb & & & & 0.15 \\
\hline
\end{tabular}

a The order of the SNPs is rs 1800872 , rs 1800871 and rs 1800896.

b Global significance were calculated in COCAPHASE [38] and 10000 permutations were done.

against TB [64]. More recently a large case-control association study (number of cases $=2010$, number of controls $=2346$ ) in Ghana determined that an IL10 haplotype was in fact associated with tuberculin skin test (TST) response and not with pulmonary disease [67]. This could not be tested for in our study.

The IL12B D5S2941 microsatellite (rs10631390), an $(\mathrm{ATT})_{\mathrm{n}}$ repeat in intron 2 of the gene, was previously associated with TB in the Hong Kong Chinese population [68]. We identified a novel (ATT) ${ }_{10}$ allele (which was confirmed by sequencing, data not shown) as well as the known $(\mathrm{ATT})_{7},(\mathrm{ATT})_{8}$ and $(\mathrm{ATT})_{9}$ alleles of the D5S2941 microsatellite in the SAC population. However, none of these were associated with TB in our study (Additional file 2). In previous studies done in Caucasian-Americans [69] and Hong Kong Chinese [68], only the (ATT) ${ }_{8}$ and $(\mathrm{ATT})_{9}$ alleles of this STR were ever observed, although the presence of the $(\mathrm{ATT})_{7}$ allele in two Swedish families was mentioned in a diabetes study [30]. There are no reports concerning this marker in African populations. Since the $(\mathrm{ATT})_{7},(\mathrm{ATT})_{8}$ and $(\mathrm{ATT})_{9}$ alleles were previously identified in individuals from European and Asian descent, we speculate that the (ATT $)_{10}$ allele is a genetic contribution from the African parental population of the SAC. The 3'UTR IL12B SNP (rs3212227) [70,71] may influence gene expression levels and has previously been associated with TB in various populations [68,72-74], but not in all $[60,75,76]$. This polymorphism was not associated with TB in our study either. Even though none of the other $I L 12 B$ polymorphisms investigated were associated with TB in the single-point analysis (similar to the results published by Kusuhara et al. [77] for rs11135058, rs2288831 and rs6870828), we found a nominally significant association between a haplotype in $I L 12 B$ and resistance to TB in the SAC population (Figure 1, Table 3). The haplotype occurred more frequently in controls than in cases $(\mathrm{p}=0.02$, OR $=1.53,95 \% \mathrm{CI}[1.07-2.02])$ and was tagged by the A allele of the rs2853696 SNP, which was

Table 2: IL 10 four SNP haplotype analysis.

\begin{tabular}{|c|c|c|c|c|}
\hline Block 1a & & Frequency Cases & Frequency Controls & p value \\
\hline 1 & T-A-T-A & 0.31 & 0.34 & 0.12 \\
\hline 2 & C-C-C-G & 0.29 & 0.29 & 0.91 \\
\hline 3 & C-C-C-A & 0.20 & 0.18 & 0.18 \\
\hline 4 & T-C-C-A & 0.17 & 0.16 & 0.36 \\
\hline 5 & T-C-C-G & 0.03 & 0.03 & 0.81 \\
\hline Global significanceb & & & & 0.44 \\
\hline
\end{tabular}

a The order of the SNPs is rs3024496, rs1800872, rs1800871, rs1800896.

b Global significance were calculated in COCAPHASE [38] and 10000 permutations were done. 


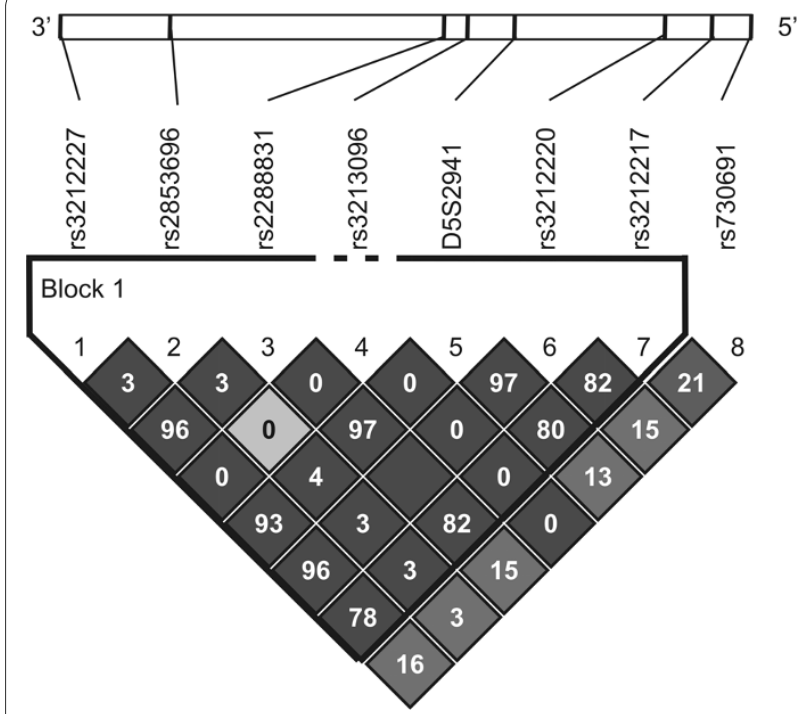

Figure 1 Plot of LD between IL12B markers analysed in control individuals of the SAC population. Generated by Haploview v4.1. The $5^{\prime}$ and $3^{\prime}$ ends of the genes are indicated and $r^{2}$ values (\%) are shown on the squares (no value $=100 \%$ ). The colours of the squares represent $D^{\prime}$ values, with dark grey being $D^{\prime}=1$, and white $D^{\prime}=0$.

not associated with TB on its own. However, after permutation testing this association was not globally significant $(\mathrm{p}=0.11)$.

Akahoshi et al. [78] reported the first case-control association study assessing IL12RB1 in TB susceptibility in the general population. Two common haplotypes (consisting of 4 SNPs, of which rs375947 was genotyped in our study) were identified, and homozygosity for the allele 2 haplotype was significantly associated with TB in Japan. Healthy subjects with this haplotype had lower levels of IL-12-induced signalling. Remus et al. [79] investigated IL12RB1 in 101 Moroccan families where two promoter polymorphisms in strong LD with each other (rs436857 and rs393548) were associated with disease, but no association was detected with the haplotype reported by Akahoshi et al. [78]. A second study done in Japan showed that two intronic SNPs were associated with disease, and a haplotype consisting of different SNPs to that identified by Akahoshi et al., was associated with resistance to TB [77]. However, this study did not replicate the association found with the promoter polymorphisms in the Moroccan families. Our investigation of the SAC population, genotyping larger sample sizes than the two positive reports from Japan [77,78], did not detect any association with $I L 12 R B 1$ SNPs (Additional file 2) or haplotypes (data not shown). Studies in Korea [80] and Indonesia [81] could not validate the findings either. The association found in Japan could be population-specific, but it could also a false-positive result. For this reason, replication of those results should be attempted in an independent, larger Asian population [81].

Promoter polymorphisms in IL12RB2 were also investigated, since this gene was previously associated with leprosy [82], an infectious disease caused by Mycobacterium leprae. Coding SNPs in this gene were previously shown to have no influence on mycobacterial infection $[78,80]$, but the degree of expression of this gene, possibly regulated by promoter polymorphisms, could determine the intensity of the cell-mediated immune response to mycobacteria [82]. However rs3762317, which disrupts a GATA transcription factor binding site [33], and rs11576006, which participates in the creation of another GATA site [33], were not associated with TB in our study.

IL-18 is a proinflammatory cytokine and, together with IL-12, one of the primary inducers of IFN- $\gamma$ production by $\mathrm{T}$ cells $[83,84]$. To date only one other association study between polymorphisms in IL18 and susceptibility to TB has been published, namely a study by Kusuhara et

Table 3: Haplotype analysis of IL12B.

\begin{tabular}{|c|c|c|c|c|}
\hline Block 1a & & Frequency Cases & Frequency Controls & p value \\
\hline 1 & A-G-T-S-G-G & 0.63 & 0.62 & 0.61 \\
\hline 2 & C-G-C-L-T-C & 0.25 & 0.24 & 0.49 \\
\hline 3 & A-A-T-S-G-G & 0.06 & 0.09 & 0.02 \\
\hline 4 & C-G-C-L-T-G & 0.03 & 0.04 & 0.38 \\
\hline Global significanceb & & & & 0.11 \\
\hline
\end{tabular}


al. which considered 21 candidate genes including IL18 [77]. Amongst others, they genotyped 6 SNPs spread throughout $I L 18$, but did not consider the functional promoter or synonymous polymorphisms, and found no association between this gene and TB susceptibility. We genotyped functional promoter polymorphisms, the synonymous SNP and other variants, but did not detect statistically significant associations in single SNP or haplotype analyses either.

Both the innate and acquired immune systems are necessary to eradicate mycobacteria from the host [20]. A microarray-based gene-expression screening of mycobacteria-infected macrophages was done to search for novel regulatory pathways in innate responses to infection [85]. This study suggested that the Wingless/Frizzled (WNT/ FZD) signalling system connects the innate and adaptive immunity during infections and implicated the WNT5A protein in human defence against infection with $M$. tuberculosis [85]. Blumenthal et al. [85] demonstrated that WNT5A is expressed by antigen-presenting cells when they are stimulated by mycobacteria or other bacterial structures. In addition, both WNT5A and its receptor FZD5, regulate IL-12 and IFN- $\gamma$ production in antigenpresenting cells when exposed to mycobacteria. None of the WNT5A or FZD5 SNPs genotyped was associated with disease in the case-control. In addition, no haplotypes from these genes were associated with TB either.

Perhaps surprisingly, our study did not validate some previously described findings, even though it had enough power to detect the effect sizes reported by those studies (Additional file 2). Some of those associations were based on extremely low sample numbers (which could lead to false positive associations) or did not correct for multiple testing. Underpowered studies may not detect effect sizes that are small, but reasonable considering the current understanding of the host genetics of complex diseases [86]. The question of correcting for multiple tests (and which method to use) is a contentious one [87] and it is often bypassed. However, the lack of reproducibility of certain associations could also be a result of ethnic-specific associations. Alternatively, polymorphisms could have smaller effect sizes in the SAC population than we were able to detect with our sample (see Statistical Analysis and Additional file 2). It is also probable that the polymorphisms studied here are associated with primary infection in the SAC population, a hypothesis which we would not be able to test due to the high incidence of latent TB infection in the control community where sample collection was done. Our study was more likely to test the possible associations of the SNPs with TB progression from latent infection to active disease only, but we cannot rule out the possibility that some controls were not TST positive as TSTs were not done. However, our previous study of healthy children and young adults from the con- trol community found that $80 \%$ of children older than 15 years had positive tuberculin skin tests, an indication of latent infection with $M$. tuberculosis [88].

The findings presented here demonstrate the common phenomenon in association studies, where the first report is usually a positive association and subsequent studies are often negative. Unfortunately, because of publication bias, other association studies which considered these eight candidate genes and found results similar to ours may not have been published.

\section{Conclusions}

We found a nominally significant association with an IL $12 B$ haplotype which was not considered to be globally significant after permutation testing to determine the significance for the entire analysis, and we identified a novel allele of the IL12B D5S2941 microsatellite in the SAC population. This research illustrates the complexity of TB where a well-known pathway cannot be conclusively genetically associated with the disease.

\section{Additional material}

Additional file 1 Previous association studies of tuberculosis susceptibility candidate genes investigated in this study. A table which summarises previous association studies of candidate genes investigated in this study.

Additional file $\mathbf{2}$ Candidate genes and polymorphisms analysed in this study. A table containing the results of the single-point association analyses done in this study.

\section{Competing interests}

The authors declare that they have no competing interests.

\section{Authors' contributions}

The work presented in the article was carried out in collaboration between all authors. MM participated in the study design and genotyping experiments, analysed the data, interpreted the results and wrote the paper. AN, PDVH, SS and EGH participated in the study design, interpreted results and wrote the paper. All authors approved the final manuscript.

\section{Acknowledgements}

Sample collection was funded by a grant from the Wellcome Trust (053844/Z/ 98/Z) to Paul van Helden and Eileen Hoal. Genotyping was funded by the German National Genome Research Network and supported by the DFG Excellence Cluster "Inflammation at Interfaces". We thank all study participants for their cooperation; E. Hanekom Keet, T. Wesse, L. Bossen, M. Davids, A. Dietsch and M. Friskovec for technical help and R. Vogler for database support.

\section{Author Details}

'Molecular Biology and Human Genetics, MRC Centre for Molecular and Cellular Biology and the DST/NRF Centre of Excellence for Biomedical TB Research, Faculty of Health Sciences, PO Box 19063, Stellenbosch University, Tygerberg 7505, South Africa and 2Institute for Clinical Molecular Biology, Christian-Albrechts-University, Schittenhelmstrasse 12, 24105 Kiel, Germany

Received: 5 February 2010 Accepted: 7 June 2010 Published: 7 June 2010

\section{References}

1. Comstock GW: Tuberculosis in twins: a re-analysis of the Prophit survey. Am Rev Respir Dis 1978, 117:621-624. 
2. Jepson A, Fowler A, Banya W, Singh M, Bennett S, Whittle H, Hill AV: Genetic regulation of acquired immune responses to antigens of Mycobacterium tuberculosis a study of twins in West Africa. Infect Immun 2001, 69:3989-3994.

3. Kallmann FJ, Reisner D: Twin studies on the significance of genetic factors in tuberculosis. Am Rev Tuberc 1942, 47:549-547.

4. Newport MJ, Goetghebuer T, Weiss HA, Whittle H, Siegrist CA, Marchant A: Genetic regulation of immune responses to vaccines in early life. Genes Immun 2004, 5:122-129.

5. Kimman $T G$, Janssen $R$, Hoebee $B$ : Future prospects in respiratory syncytial virus genetics. Future Virology 2006, 1:483-492.

6. Cobat A, Gallant CJ, Simkin L, Black GF, Stanley K, Hughes J, Doherty TM, Hanekom WA, Eley B, Beyers N, Jaïs J, van Helden PD, Abel L, Hoal EG, Alcaïs A, Schurr E: High heritability of anti-mycobacterial immunity in a hyper-endemic area for tuberculosis disease. J Infect Dis 2010, 201:15-19.

7. Möller M, de Wit E, Hoal EG: Past, present and future directions in human genetic susceptibility to tuberculosis. FEMS Immunol Med Microbiol 2010, 58:3-26.

8. van Helden PD, Möller M, Babb C, Warren R, Walzl G, Uys P, Hoal E: TB epidemiology and human genetics. Novartis Found Symp 2006, 279:17-31.

9. Leal IS, Smedegard B, Andersen P, Appelberg R: Failure to induce enhanced protection against tuberculosis by increasing T-celldependent interferon-gamma generation. Immunology 2001, 104:157-161.

10. Cooper AM, Dalton DK, Stewart TA, Griffin JP, Russell DG, Orme IM: Disseminated tuberculosis in interferon gamma gene-disrupted mice. J Exp Med 1993, 178:2243-2247.

11. Moreira AL, Tsenova L, Murray PJ, Freeman S, Bergtold A, Chiriboga L, Kaplan G: Aerosol infection of mice with recombinant BCG secreting murine IFN-gamma partially reconstitutes local protective immunity. Microb Pathog 2000, 29:175-185.

12. Hirsch CS, Toossi Z, Othieno C, Johnson JL, Schwander SK, Robertson S, Wallis RS, Edmonds K, Okwera A, Mugerwa R, Peters P, Ellner JJ: Depressed $T$-cell interferon-gamma responses in pulmonary tuberculosis: analysis of underlying mechanisms and modulation with therapy. J Infect Dis 1999, 180:2069-2073.

13. Jo EK, Park JK, Dockrell HM: Dynamics of cytokine generation in patients with active pulmonary tuberculosis. Curr Opin Infect Dis 2003, 16:205-210

14. Ribeiro-Rodrigues R, Resende CT, Johnson JL, Ribeiro F, Palaci M, Sa RT, Maciel EL, Pereira Lima FE, Dettoni V, Toossi Z, Boom WH, Dietze R, Ellner $J$, Hirsch CS: Sputum cytokine levels in patients with pulmonary tuberculosis as early markers of mycobacterial clearance. Clin Diagn Lab Immunol 2002, 9:818-823.

15. Lin PL, Rodgers M, Smith L, Bigbee M, Myers A, Bigbee C, Chiosea I, Capuano SV, Fuhrman C, Klein E, Flynn J: Quantitative comparison of active and latent tuberculosis in the cynomolgus macaque model. Infect Immun 2009, 77:4631-4642.

16. Doherty TM, Demissie A, Olobo J, Wolday D, Britton S, Equale T, Ravn P, Andersen P: Immune responses to the Mycobacterium tuberculosisspecific antigen ESAT- 6 signal subclinical infection among contacts of tuberculosis patients. J Clin Microbio/ 2002, 40:704-706.

17. Winek J, Rowinska-Zakrzewska E, Demkow U, Szopinski J, Szolkowska M, Filewska M, Jagodzinski J, Roszkowski-Sliz K: Interferon gamma production in the course of Mycobacterium tuberculosis infection. $J$ Physiol Pharmacol 2008, 59(Suppl 6):751-759.

18. Park SK, Cho S, Lee IH, Jeon DS, Hong SH, Smego RA Jr, Cho SN: Subcutaneously administered interferon-gamma for the treatment of multidrug-resistant pulmonary tuberculosis. Int J Infect Dis 2007, 11:434-440.

19. Roberts T, Beyers N, Aguirre A, Walzl G: Immunosuppression during Active Tuberculosis Is Characterized by Decreased Interferon-gamma Production and CD25 Expression with Elevated Forkhead Box P3, Transforming Growth Factor-beta, and Interleukin-4 mRNA Levels. J Infect Dis 2007, 195:870-878.

20. Flynn JL, Chan J: Immunology of tuberculosis. Annu Rev Immuno/ 2001 19:93-129.

21. Mittrücker HW, Steinhoff U, Kohler A, Krause M, Lazar D, Mex P, Miekley D, Kaufmann $\mathrm{SH}$ : Poor correlation between BCG vaccination-induced $\mathrm{T}$ cell responses and protection against tuberculosis. Proc Natl Acad Sci USA 2007, 104:12434-12439.

22. Buddle BM, Wedlock DN, Denis M, Skinner MA: Identification of immune response correlates for protection against bovine tuberculosis. Vet Immunol Immunopathol 2005, 108:45-51.

23. Al-Muhsen S, Casanova JL: The genetic heterogeneity of mendelian susceptibility to mycobacterial diseases. J Allergy Clin Immunol 2008 122:1043-1051

24. Rossouw M, Nel HJ, Cooke GS, van Helden PD, Hoal EG: Association between tuberculosis and a polymorphic NFkappaB binding site in the interferon gamma gene. Lancet 2003, 361:1871-1872

25. Pacheco AG, Cardoso CC, Moraes MO: IFNG +874T/A, IL10-1082G/A and TNF-308G/A polymorphisms in association with tuberculosis susceptibility: a meta-analysis study. Hum Genet 2008, 123:477-484.

26. Shibasaki M, Yagi T, Yatsuya H, Okamoto M, Nishikawa M, Baba H, Hashimoto N, Senda K, Kawabe T, Nakashima K, Imaizumi K, Shimokata K, Hasegawa Y: An influence of Interferon-gamma gene polymorphisms on treatment response to tuberculosis in Japanese population. J Infect 2009, 58:467-469.

27. Kritzinger FE, den BS, Verver S, Enarson DA, Lombard CJ, Borgdorff MW, Gie RP, Beyers N: No decrease in annual risk of tuberculosis infection in endemic area in Cape Town, South Africa. Trop Med Int Health 2009, 14:136-142

28. Incidence Of TB In The Provinces Of South Africa [http:// www.hst.org.za/healthstats/16/data]

29. Barreiro LB, Neyrolles O, Babb CL, Tailleux L, Quach H, McElreavey K, Helden PD, Hoal EG, Gicquel B, Quintana-Murci L: Promoter Variation in the DC-SIGN Encoding Gene CD209 Is Associated with Tuberculosis. PLoS Medicine 2006, 3:e20.

30. Bergholdt R, Ghandil P, Johannesen J, Kristiansen OP, Kockum I, Luthman $\mathrm{H}$, Ronningen KS, Nerup J, Julier C, Pociot F: Genetic and functional evaluation of an interleukin-12 polymorphism (IDDM18) in families with type 1 diabetes. J Med Genet 2004, 41:e39.

31. Hampe J, Wollstein A, Lu T, Frevel HJ, Will M, Manaster C, Schreiber S: An integrated system for high throughput TaqMan based SNP genotyping. Bioinformatics (Oxford, England) 2001, 17:654-655.

32. Teuber M, Koch WA, Manaster C, Wachter S, Hampe J, Schreiber S: Improving quality control and workflow management in highthroughput single-nucleotide polymorphism genotyping environments. Journal of the Association for Laboratory Automation 2005, 10:43-47.

33. van Rietschoten JG, Westland $R$, van den Bogaard R, Nieste-Otter MA, van Veen A, Jonkers RE, van der Pouw Kraan TC, den Hartog MT, Wierenga EA: A novel polymorphic GATA site in the human IL-12Rbeta2 promoter region affects transcriptional activity. Tissue Antigens 2004, 63:538-546.

34. Lee EY, Yim JJ, Lee HS, Lee YJ, Lee EB, Song YW: Dinucleotide repeat polymorphism in intron II of human Toll-like receptor 2 gene and susceptibility to rheumatoid arthritis. Int J Immunogenet 2006 33:211-215

35. Yamada N, Yamaya M, Okinaga S, Nakayama K, Sekizawa K, Shibahara S, Sasaki H: Microsatellite polymorphism in the heme oxygenase-1 gene promoter is associated with susceptibility to emphysema. Am J Hum Genet 2000, 66:187-195.

36. McGinnis RE, Spielman RS: Insulin gene 5 ' flanking polymorphism Length of class 1 alleles in number of repeat units. Diabetes 1995, 44:1296-1302

37. Nicodemus KK, Liu W, Chase GA, Tsai YY, Fallin MD: Comparison of type I error for multiple test corrections in large single-nucleotide polymorphism studies using principal components versus haplotype blocking algorithms. BMC Genet 2005, 6(Suppl 1):S78

38. Dudbridge F: Pedigree disequilibrium tests for multilocus haplotypes. Genet Epidemiol 2003, 25:115-121.

39. Barrett JC, Fry B, Maller J, Daly MJ: Haploview: analysis and visualization of LD and haplotype maps. Bioinformatics (Oxford, England) 2005, 21:263-265.

40. Luoni G, Verra F, Arca B, Sirima BS, Troye-Blomberg M, Coluzzi M, Kwiatkowski D, Modiano D: Antimalarial antibody levels and IL4 polymorphism in the Fulani of West Africa. Genes Immun 2001, 2:411-414.

41. Rosenwasser $L$, Klemm DJ, Dresback JK, Inamura H, Mascali JJ, Klinnert M, Borish L: Promoter polymorphisms in the chromosome 5 gene cluster in asthma and atopy. Clin Exp Allergy 1995, 25(Suppl 2):74-78. 
42. Vidyarani M, Selvaraj P, Prabhu AS, Jawahar MS, Adhilakshmi AR, Narayanan PR: Interferon gamma (IFNgamma) \& interleukin-4 (IL-4) gene variants \& cytokine levels in pulmonary tuberculosis. Indian J Med Res 2006, 124:403-410.

43. Naslednikova IO, Urazova OI, Voronkova OV, Strelis AK, Novitsky VV, Nikulina EL, Hasanova RR, Kononova TE, Serebryakova VA, Vasileva OA, Suhalentseva NA, Churina EG, Kolosova AE, Fedorovich TV: Allelic polymorphism of cytokine genes during pulmonary tuberculosis. Bull Exp Biol Med 2009, 148:175-180.

44. Bellamy R: Genetic susceptibility and resistance to tuberculosis. In PhD Thesis University of Oxford, Faculty of Clinical Medicine; 1998.

45. Vasiliev AM, Vasilenko RN, Kulikova NL, Andreev SM, Chikileva IO, Puchkova GY, Kosarev IV, Khodyakova AV, Khlebnikov VS, Ptitsyn LR, Shcherbakov GY, Uversky VN, DuBuske LM, Abramov VM: Structural and functional properties of IL-4delta2, an alternative splice variant of human IL-4. J Proteome Res 2003, 2:273-281.

46. Demissie A, Abebe M, Aseffa A, Rook G, Fletcher H, Zumla A, Weldingh K, Brock I, Andersen P, Doherty TM: Healthy individuals that control a latent infection with Mycobacterium tuberculosis express high levels of Th1 cytokines and the IL-4 antagonist IL-4delta2. J Immuno/ 2004, 172:6938-6943.

47. Dheda K, Chang JS, Breen RA, Kim LU, Haddock JA, Huggett JF, Johnson MA, Rook GA, Zumla A: In vivo and in vitro studies of a novel cytokine, interleukin 4delta2, in pulmonary tuberculosis. Am J Respir Crit Care Med 2005, 172:501-508.

48. Dheda K, Chang JS, Huggett JF, Kim LU, Johnson MA, Zumla A, Rook GA: The stability of mRNA encoding IL-4 is increased in pulmonary tuberculosis, while stability of mRNA encoding the antagonistic splice variant, IL-4delta2, is not. Tuberculosis (Edinb) 2007, 87:237-241.

49. Babb C, van der Merwe L, Beyers N, Pheiffer C, Walzl G, Duncan K, van Helden $\mathrm{P}$, Hoal EG: Vitamin D receptor gene polymorphisms and sputum conversion time in pulmonary tuberculosis patients. Tuberculosis 2007, 87:295-302.

50. Turner DM, Williams DM, Sankaran D, Lazarus M, Sinnott PJ, Hutchinson IV: An investigation of polymorphism in the interleukin-10 gene promoter. Eur J Immunogenet 1997, 24:1-8.

51. Rosenwasser $L J$, Borish L: Genetics of atopy and asthma: the rationale behind promoter-based candidate gene studies (IL-4 and IL-10). Am J Respir Crit Care Med 1997, 156:S152-S155.

52. Shin HD, Winkler C, Stephens JC, Bream J, Young H, Goedert JJ, O'Brien TR, Vlahov D, Buchbinder S, Giorgi J, Rinaldo C, Donfield S, Willoughby A, O'Brien SJ, Smith MW: Genetic restriction of HIV-1 pathogenesis to AIDS by promoter alleles of IL10. Proc Natl Acad Sci USA 2000, 97:14467-14472.

53. Edwards-Smith CJ, Jonsson JR, Purdie DM, Bansal A, Shorthouse C, Powell EE: Interleukin-10 promoter polymorphism predicts initial response of chronic hepatitis C to interferon alfa. Hepatology 1999, 30:526-530.

54. Delgado JC, Baena A, Thim S, Goldfeld AE: Ethnic-specific genetic associations with pulmonary tuberculosis. J Infect Dis 2002, 186:1463-1468

55. Scola L, Crivello A, Marino V, Gioia V, Serauto A, Candore G, ColonnaRomano G, Caruso C, Lio D: IL-10 and TNF-alpha polymorphisms in a sample of Sicilian patients affected by tuberculosis: implication for ageing and life span expectancy. Mech Ageing Dev 2003, 124:569-572.

56. Oral HB, Budak F, Uzaslan EK, Basturk B, Bekar A, Akalin H, Ege E, Ener B, Goral G: Interleukin-10 (IL-10) gene polymorphism as a potential host susceptibility factor in tuberculosis. Cytokine 2006, 35:143-147.

57. Tso HW, Ip WK, Chong WP, Tam CM, Chiang AK, Lau YL: Association of interferon gamma and interleukin 10 genes with tuberculosis in Hong Kong Chinese. Genes Immun 2005, 6:358-363.

58. Bellamy R, Ruwende C, Corrah T, McAdam KP, Whittle HC, Hill AV: Assessment of the interleukin 1 gene cluster and other candidate gene polymorphisms in host susceptibility to tuberculosis. Tuber Lung Dis 1998, 79:83-89.

59. Fitness J, Floyd S, Warndorff DK, Sichali L, Malema S, Crampin AC, Fine PE, Hill AV: Large-scale candidate gene study of tuberculosis susceptibility in the Karonga district of northern Malawi. Am J Trop Med Hyg 2004, 71:341-349.

60. Prabhu AS, Selvaraj P, Jawahar MS, Adhilakshmi AR, Narayanan PR: Interleukin-12B \& interleukin-10 gene polymorphisms in pulmonary tuberculosis. Indian J Med Res 2007, 126:135-138.

61. Lopez-Maderuelo D, Arnalich F, Serantes R, Gonzalez A, Codoceo R, Madero R, Vazquez JJ, Montiel C: Interferon-gamma and interleukin-10 gene polymorphisms in pulmonary tuberculosis. Am J Respir Crit Care Med 2003, 167:970-975.

62. Shin HD, Park BL, Kim YH, Cheong HS, Lee IH, Park SK: Common interleukin 10 polymorphism associated with decreased risk of tuberculosis. Exp MolMed 2005, 37:128-132.

63. Oh JH, Yang CS, Noh YK, Kweon YM, Jung SS, Son JW, Kong SJ, Yoon JU, Lee JS, Kim HJ, Park JK, Jo EK, Song CH: Polymorphisms of interleukin-10 and tumour necrosis factor-alpha genes are associated with newly diagnosed and recurrent pulmonary tuberculosis. Respirology 2007 12:594-598

64. Stein CM, Zalwango S, Chiunda AB, Millard C, Leontiev DV, Horvath AL, Cartier KC, Chervenak K, Boom WH, Elston RC, Mugerwa RD, Whalen CC, lyengar SK: Linkage and association analysis of candidate genes for TB and TNFalpha cytokine expression: evidence for association with IFNGR1, IL-10, and TNF receptor 1 genes. Hum Genet 2007, 121:663-673.

65. Ates $\mathrm{O}$, Musellim B, Ongen $\mathrm{G}$, Topal-Sarikaya A: Interleukin-10 and tumor necrosis factor-alpha gene polymorphisms in tuberculosis. J Clin Immunol 2008, 28:232-236.

66. Henao MI, Montes C, Paris SC, Garcia LF: Cytokine gene polymorphisms in Colombian patients with different clinical presentations of tuberculosis. Tuberculosis (Edinburgh, Scotland) 2006, 86:11-19.

67. Thye T, Browne EN, Chinbuah MA, Gyapong J, Osei I, Owusu-Dabo E, Brattig NW, Niemann S, Rusch-Gerdes S, Horstmann RD, Meyer CG: IL10 haplotype associated with tuberculin skin test response but not with pulmonary TB. PLOS ONE 2009, 4:e5420.

68. Tso HW, Lau YL, Tam CM, Wong HS, Chiang AK: Associations between IL12B Polymorphisms and Tuberculosis in the Hong Kong Chinese Population. J Infect Dis 2004, 190:913-919.

69. Davoodi-Semiromi A, Yang JJ, She JX: IL-12p40 is associated with type 1 diabetes in Caucasian-American families. Diabetes 2002, 51:2334-2336.

70. Hall MA, McGlinn E, Coakley G, Fisher SA, Boki K, Middleton D, Kaklamani E, Moutsopoulos H, Loughran TP Jr, Ollier WE, Panayi GS, Lanchbury JS: Genetic polymorphism of IL-12 p40 gene in immune-mediated disease. Genes Immun 2000, 1:219-224.

71. Huang D, Cancilla MR, Morahan G: Complete primary structure, chromosomal localisation, and definition of polymorphisms of the gene encoding the human interleukin-12 p40 subunit. Genes Immun 2000, 1:515-520

72. Akahoshi M, Ishihara M, Remus N, Uno K, Miyake K, Hirota T, Nakashima K, Matsuda A, Kanda M, Enomoto T, Ohno S, Nakashima H, Casanova JL, Hopkin JM, Tamari M, Mao XQ, Shirakawa T: Association between IFNA genotype and the risk of sarcoidosis. Hum Genet 2004, 114:503-509.

73. Morahan G, Kaur G, Singh M, Rapthap CC, Kumar N, Katoch K, Mehra NK, Huang D: Association of variants in the IL12B gene with leprosy and tuberculosis. Tissue Antigens 2007, 69(Suppl 1):234-236.

74. Freidin MB, Rudko AA, Kolokolova OV, Strelis AK, Puzyrev VP: Association between the $1188 \mathrm{~A} / \mathrm{C}$ polymorphism in the human IL12B gene and Th1-mediated infectious diseases. Int J Immunogenet 2006, 33:231-232.

75. Ma X, Reich RA, Gonzalez O, Pan X, Fothergill AK, Starke JR, Teeter LD, Musser JM, Graviss EA: No evidence for association between the polymorphism in the 3 ' untranslated region of interleukin-12B and human susceptibility to tuberculosis. Journal of Infectious Diseases 2003, 188:1116-1118

76. Puzyrev VP, Freidin MB, Rudko AA, Strelis AK, Kolokolova OV: [Polymorphisms of the candidate genes for genetic susceptibility to tuberculosis in the Slavic population of Siberia: a pilot study]. Mol Biol (Mosk) 2002, 36:788-791.

77. Kusuhara K, Yamamoto K, Okada K, Mizuno Y, Hara T: Association of IL12RB1 polymorphisms with susceptibility to and severity of tuberculosis in Japanese: a gene-based association analysis of 21 candidate genes. Int J Immunogenet 2007, 34:35-44.

78. Akahoshi M, Nakashima H, Miyake K, Inoue Y, Shimizu S, Tanaka Y, Okada K, Otsuka T, Harada M: Influence of interleukin-12 receptor beta1 polymorphisms on tuberculosis. Hum Genet 2003, 112:237-243.

79. Remus N, El Baghdadi J, Fieschi C, Feinberg J, Quintin T, Chentoufi M Schurr E, Benslimane A, Casanova JL, Abel L: Association of IL12RB1 polymorphisms with pulmonary tuberculosis in adults in Morocco. $J$ Infect Dis 2004, 190:580-587.

80. Lee HW, Lee HS, Kim DK, Ko DS, Han SK, Shim YS, Yim JJ: Lack of an association between interleukin-12 receptor beta1 polymorphisms and tuberculosis in Koreans. Respiration 2005, 72:365-368. 
81. Sahiratmadja E, Baak-Pablo R, de Visser AW, Alisjahbana B, Adnan I, van Crevel R, Marzuki S, van Dissel JT, Ottenhoff TH, Van DV: Association of polymorphisms in IL-12/IFN-gamma pathway genes with susceptibility to pulmonary tuberculosis in Indonesia. Tuberculosis (Edinb) 2007 87:303-311.

82. Ohyama H, Ogata K, Takeuchi K, Namisato M, Fukutomi Y, Nishimura F, Naruishi H, Ohira T, Hashimoto K, Liu T, Suzuki M, Uemura Y, Matsushita S: Polymorphism of the 5 ' flanking region of the IL-12 receptor beta2 gene partially determines the clinical types of leprosy through impaired transcriptional activity. J Clin Pathol 2005, 58:740-743.

83. Lee JS, Song CH, Kim CH, Kong SJ, Shon MH, Kim HJ, Park JK, Paik TH, Jo EK: Profiles of IFN-gamma and its regulatory cytokines (IL-12, IL-18 and IL10 ) in peripheral blood mononuclear cells from patients with multidrug-resistant tuberculosis. Clin Exp Immunol 2002, 128:516-524.

84. Dinarello CA, Novick D, Puren AJ, Fantuzzi G, Shapiro L, Muhl H, Yoon DY Reznikov LL, Kim SH, Rubinstein M: Overview of interleukin-18: more than an interferon-gamma inducing factor. J Leukoc Biol 1998, 63:658-664

85. Blumenthal A, Ehlers S, Lauber J, Buer J, Lange C, Goldmann T, Heine H, Brandt E, Reiling N: The Wingless homolog WNT5A and its receptor Frizzled-5 regulate inflammatory responses of human mononuclear cells induced by microbial stimulation. Blood 2006, 108:965-973.

86. Ioannidis JP, Ntzani EE, Trikalinos TA, Contopoulos-loannidis DG: Replication validity of genetic association studies. Nat Genet 2001, 29:306-309.

87. van den Oord EJ: Controlling false discoveries in genetic studies. Am J Med Genet B Neuropsychiatr Genet 2008, 147B:637-644.

88. Gallant CJ, Cobat A, Simkin L, Black GF, Stanley K, Hughes J, Doherty TM, Hanekom WA, Eley B, Beyers N, van Helden P, Abel L, Alcaïs A, Hoal EG, Schurr E: The impact of age and sex on anti-mycobacterial immunity of children and adolescents in an area of high tuberculosis incidence. IJTLD in press.

\section{Pre-publication history}

The pre-publication history for this paper can be accessed here: http://www.biomedcentral.com/1471-2334/10/154/prepub

Submit your next manuscript to BioMed Central and take full advantage of:

- Convenient online submission

- Thorough peer review

- No space constraints or color figure charges

- Immediate publication on acceptance

- Inclusion in PubMed, CAS, Scopus and Google Scholar

- Research which is freely available for redistribution

Submit your manuscript at www.biomedcentral.com/submit
C Biomed Central 